\title{
The attitude of Turkish general surgeons during the COVID-19 pandemic: results of "general surgery COVID-19 pandemic attitude survey"
}

\author{
Muhammet Kadri Çolakoğlu(D), Yiğit Mehmet Özgün ${ }^{1}$ (D), Erol Pişkin ${ }^{1}$ (D), Erdal Birol Bostancı ${ }^{1}$ (D), Mehmet Mahir Özmen²(D) \\ 1 Department of Gastrointestinal Surgery, Health Sciences University, Ankara City Hospital, Ankara, Turkey \\ ${ }^{2}$ Department of Surgery, Istinye University School of Medicine, Istanbul/Liv Hospital Ankara, Ankara, Turkey
}

\begin{abstract}
Objective: The whole world is dealing with the COVID-19 pandemic, and healthcare professionals are the most affected group. The aim of this study was to evaluate the knowledge of general surgeons about COVID-19 and understand the attitude and current situation of our colleagues.

Material and Methods: This descriptive study comprised general surgeons working in different parts of Turkey. A survey with 23 questions was prepared to determine the demographic characteristics of the participants, workplace characteristics, change in daily work practices and their attitudes in the pandemic process.

Results: A total of 332 forms were evaluated. Survey results show that the majority of surgeons have changed their daily surgical practices. Many surgeons take part in the treatment of COVID-19. While most benign cases are delayed, the managemet of malignant cases differs. There are also differences in the evaluation of patients preoperatively and the type of operation. Personal protective measures are followed. While the rate of infected surgeons is low, the majority of surgeons have concerns about infection.

Conclusion: Turkish surgeons have managed to get a quick reaction from the start of the pandemic. However, there are still differences in preoperative patient evaluation and operation selection and precautions during the operation. Surgeons also should be informed about the management of malignant patients.
\end{abstract}

Keywords: COVID-19, coronavirus, pandemic, surgery, survey

Cite this article as: Çolakoğlu MK, Özgün YM, Pişkin E Bostancı EB, Özmen MM. The attitude of Turkish general surgeons during the COVID-19 pandemic: Results of "general surgery COVID-19 pandemic attitude survey". Turk J Surg 2020; 36 (2): 137-146

\section{Corresponding Author}

Muhammet Kadri Çolakoğlu

E-mail: drkadri@gmail.com

Received: 20.04 .2020

Accepted: 21.04 .2020

Available Online Date: 06.05.2020

๑ Copyright 2020 by Turkish Surgical Society Available online at www.turkjsurg.com

DOI: $10.5578 /$ turkjsurg.4809

\section{INTRODUCTION}

There is an intense fight worldwide against the 2019-nCoV virus which has a high risk of transmission, and mortality rates increases especially in a significant group of patients. This war will have many social and economic impacts on the world, but the greatest impact at present is the impact on the healthcare system that directly interferes with healthcare providers at the forefront of the war. In this situation, which seems to have spread throughout the country and increases its density especially in metropols, hospitals had to postpone the treatment of other non-emergency diseases and devoted most of their resources to the treatment of COVID-19 patients at different levels. Similarly, different areas of expertise had to take part in this common war to meet the need or had to change their daily routines.

During the pandemic, general surgeons either take part in the primary treatment of COVID-19 patients, or undertake the surgical treatment of COVID-19 suspected or positive patients in their daily routines (1). For this reason, changes in the approach or daily practice of general surgeons raised several questions. Answering these questions will enable us to have an idea about the role of general surgeons in the pandemic process, the situation of surgical education, changes in daily surgical practice, how surgeons approach the patient and how they protect themselves and especially their pyscological well-being. The answers to these questions are very important in terms of understanding our situation as Turkish General Surgeons and giving way to the measures we will take.

In order to achieve this goal, a survey containing 23 questions was prepared and the results were evaluated. Our aim was to evaluate not only the knowledge of 
general surgeons about COVID-19 but to understand the attitude and current situation of our colleagues.

\section{MATERIAL and METHODS}

This descriptive study comprised general surgery specialists and residents working in different parts of Turkey. This study was approved by the Ministry of Health, General Directorate of Health Services. A survey with 23 questions was prepared to determine the demographic characteristics of the participants, the workplace characteristics, the change in daily work practices and their attitudes in the pandemic process. Google forms (Google Inc, California, USA) were used in the preparation of the survey. The researchers following the guidelines including the suggestions about management of surgical practices during pandemic and the World Health Organization (WHO) suggestions were involved in the preparation of the survey. After the survey had been prepared, a link was sent to the members to participate in the survey using the Turkish Surgical Society mailing list and this link was also tried to be reached to more surgeons through various social media platforms. Access to the survey was provided between 13-
17 April 2020. Results were evaluated after the survey had expired and results were expressed as mean \pm standard deviation and numbers with percentages (\%).

\section{RESULTS}

At the end of the survey period, the total number of participants reached 336 in five days. Three forms were not included in the evaluation due to missing information, and one form with a participant from North Cyprus was excluded to avoid creating bias. A total of 332 forms were evaluated. Considering the total number of general surgeons in Turkey, with this sample size, the confidence interval (margin of error) was 5.2\%, at 95\% confidence level, which was a reliable rate. The distribution of the participants across the country is shown in Figure 1. While most of the participation was from metropolitan cities, it is understood that participation from all regions of the country can be achieved.

The types of hospitals where the participants work and the rates of their density by the COVID-19 pandemic are presented in Figure 2 . COVID-19 density classification of hospitals is divided into four cat-
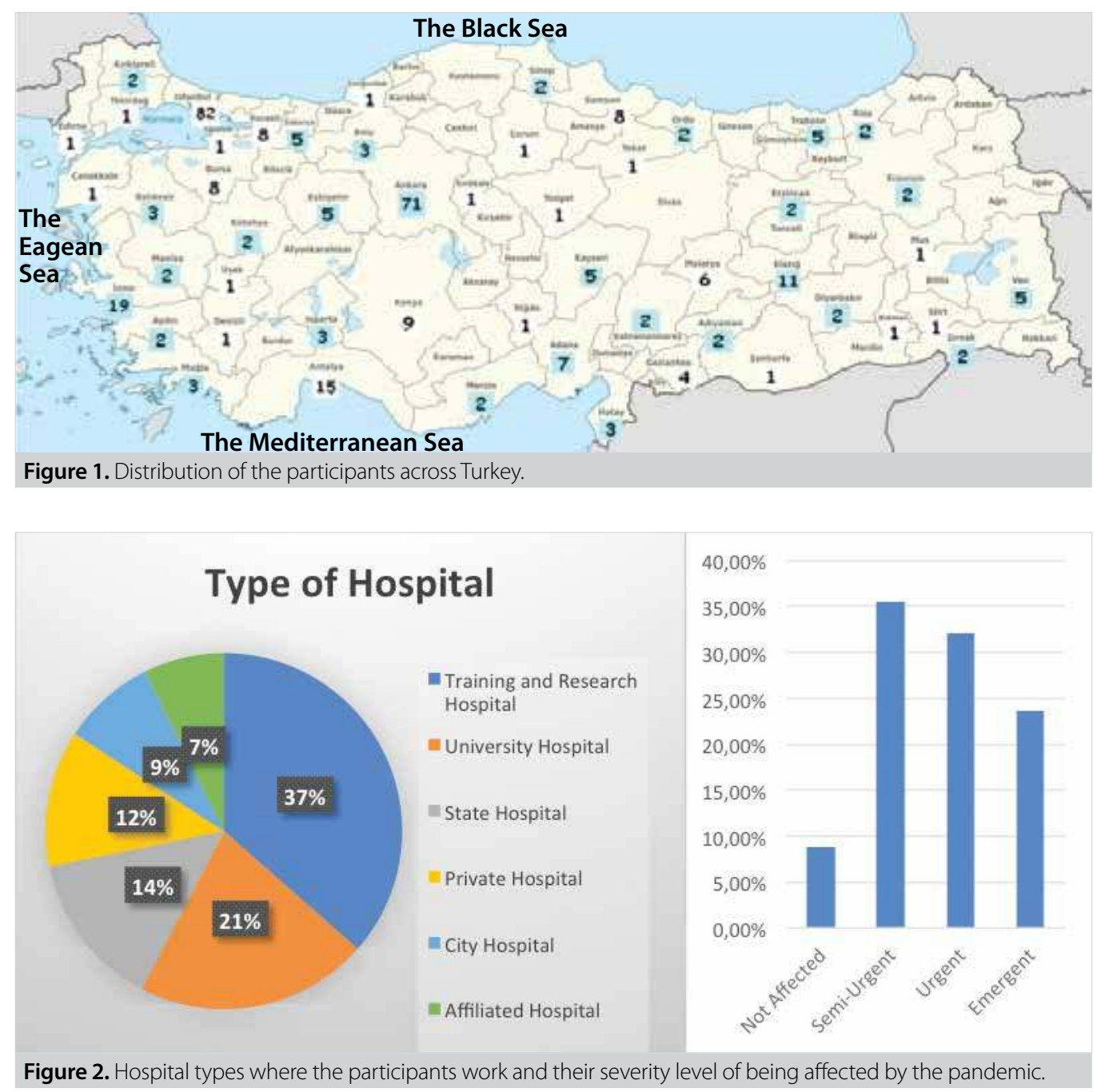
egories; 1. Unaffected: No COVID-19 patients, hospital works properly. 2. Semi-Urgent: Few COVID-19 patients, hospital resources not exhausted, institution still has intensive care unit (ICU) ventilator capacity and COVID-19 trajectory not in rapid escalation phase. 3. Urgent: Many COVID-19 patients, ICU and ventilator capacity limited, operation room (OR) supplies limited, and 4. Emergent: Hospital resources are all routed to COVID 19 patients, no ventilator or ICU capacity, OR supplies exhausted. Accordingly, while the majority of the participants (35.5\%) were found to have been working in semi-urgent hospitals, the rate of those working in emergent hospitals is $23.6 \%$. Twenty-nine surgeons (8.8\%) stated that they are still working in hospitals that have never been affected.

While questioning the daily routines of surgeons, $74.2 \%$ of surgeons reported that they stopped daily training, council and meeting activities during the pandemic process. The rest continued their meetings either by reducing the number of participants or by video conference method. The rate of those who did not change their daily activities was $4.6 \%$. These rates can be seen in Figure 3.

Figure 4 shows the changes in surgeons' daily operation practice during the pandemic process. According to this, the majority of

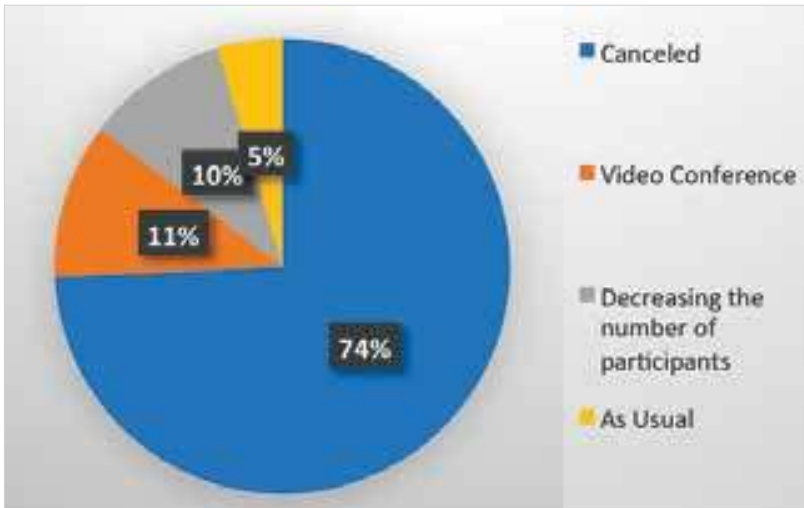

Figure 3. Changes in daily training, council and meeting activities during the pandemic process.

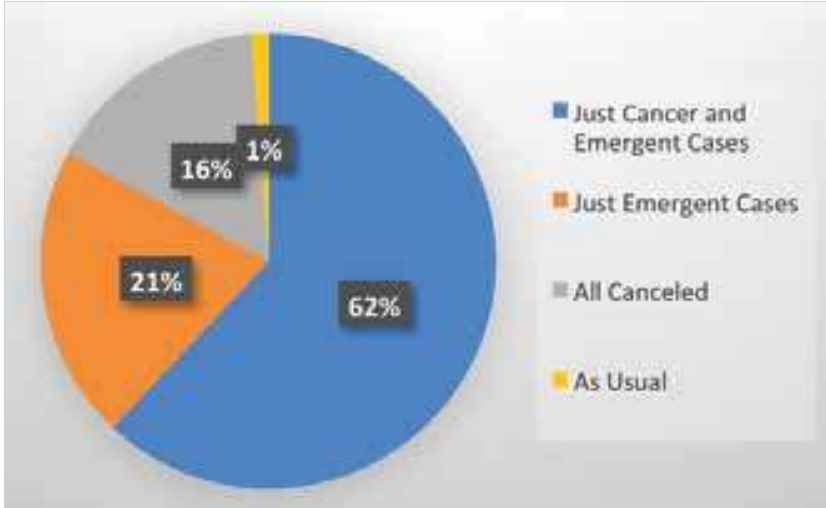

Figure 4. Changes in surgeons' daily operation practice during the pandemic process. the participants (61.8\%) stated that they only operated emergency and cancer cases. The number of surgeons who did not change operation routine was only 5 (1.5\%). Other surgeons, either only perform emergency surgeries (20.9\%) or have stopped their daily practice completely (15.8\%). When asked to the surgeons who stopped the daily operation practices completely, the majority (29.5\%) stated that they were working in other areas (polyclinic, service, intensive care) where COVID-19 patients were treated. The second major majority (26.9\%) stated that they did not perform cases because they experienced anxiety due to COVID-19. Other answers with decreasing rates were the flexible work program, lack of resources or beds due to COVID-19 and other reasons.

Then, the attitude of COVID-19 was questioned in surgeons who continued the operation, and $34.2 \%$ of surgeons stated that they considered all patients positive in the preoperative period and took precautions accordingly. The rate of making only symptomatic evaluation was $31.2 \%$, the rate of preoperative thorax computed tomography request was $20.5 \%$, and the rate of PCR request was $7.3 \%$. Seven percent of the surgeons stated that they did not perform any evaluation and that they took action if any problems developed during the process. Almost half (46.4\%) of the surgeons did not receive a consent form for COVID-19 from the patient prior to surgery. Suspected or positive patient contact and operation rates of surgeons are shown in Figure 5. Surgeons' management of benign and malignant patients in this process is presented in Figure 6. $22.7 \%(n=69)$ of the general surgeons had COVID-19 test or imaging for themselves. One percent $(n=3)$ of the participants had COVID-19 positivity and treatment.

Almost half (51.8\%) of the surgeons did not have a separate operating room reserved for COVID-19 patients. Surgeons' attitudes to using personal protection equipment in non-operating room and operating room routines are shown in Figure 7.

Four operation methods (open, laparoscopic, robotic and endoscopic) were presented in the survey and the method consid-

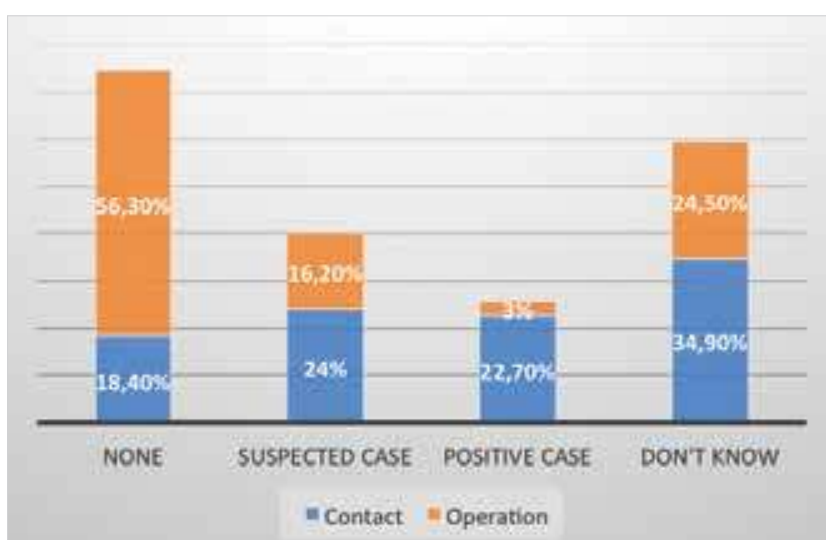

Figure 5. Suspected or positive patient contact and operation rates. 


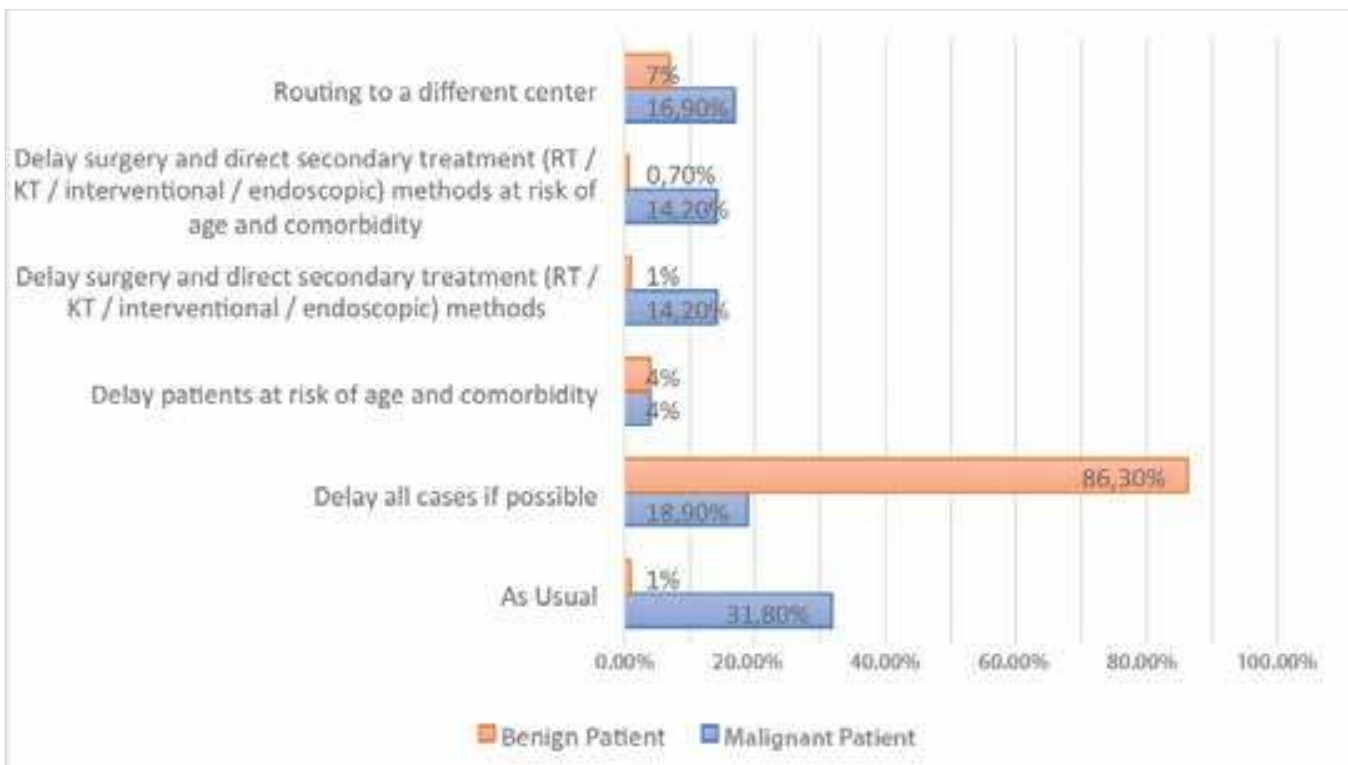

Figure 6. Surgical management choices of benign and malignant patients.

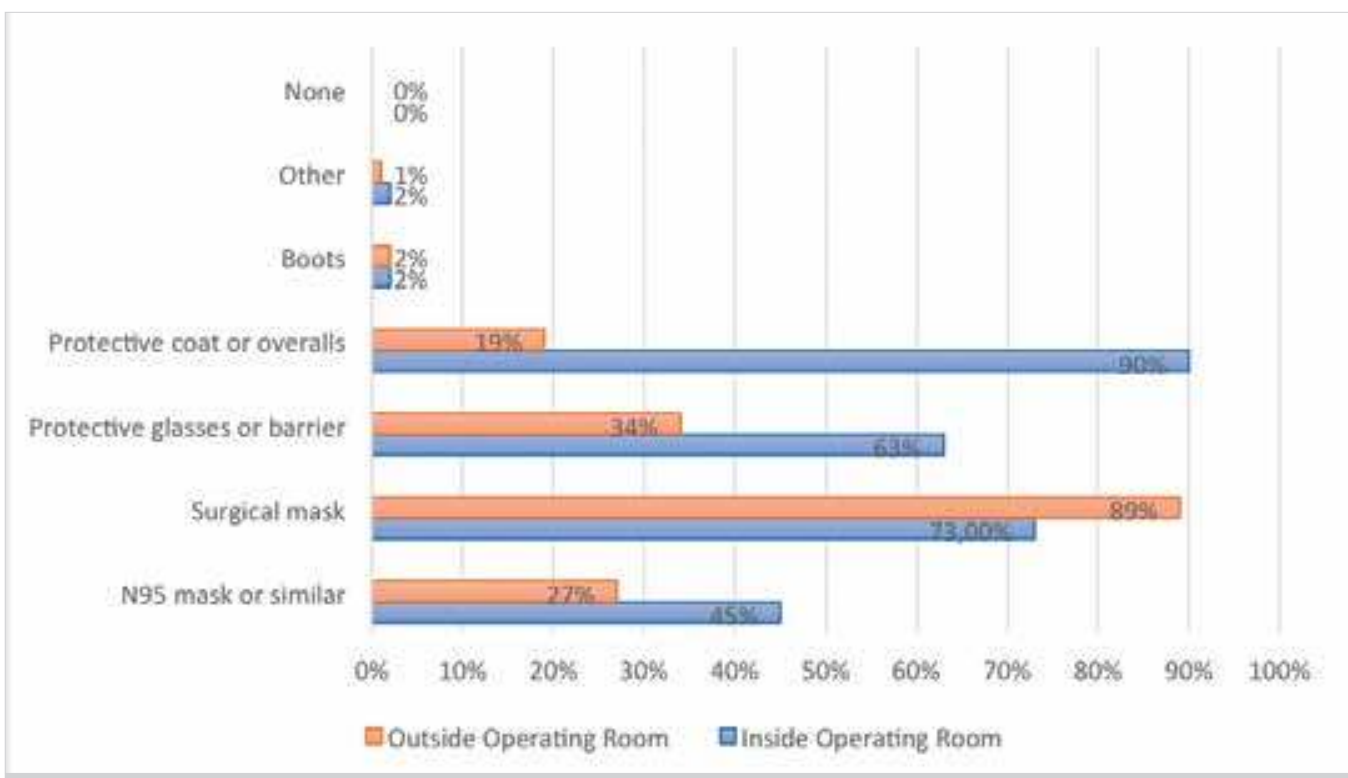

Figure 7. Surgeons' attitudes to using personal protection equipment.

ered to be the most risky in terms of COVID-19 transmission was asked. The method that received the most response with 41.9\% rate was upper endoscopic surgery, which was followed by laparoscopic, open and robotic methods, respectively. When asked for the method that is considered to be the lowest risk in terms of COVID-19 transmission, open surgery was the method with the highest response with 56\% answer rate, which was followed by robotic, laparoscopic and upper endoscopic surgery, respectively. The rate of those who took measures in open surgery to minimize the risk of COVID-19 transmission was 29.7\%, while in minimally invasive surgery this rate was $41.2 \%$.
From a social perspective, it was observed that $76.4 \%$ of the participants still stayed with their families at home during the pandemic process, $18.7 \%$ lived alone, and $4.9 \%$ resided in hotels or guesthouses. Half of the participants were concerned about being infected with COVID-19, 76\% were afraid to carry COVID-19 infection to their relatives. The rate of those who stated that they did not experience these concerns was $20.4 \%$.

\section{DISCUSSION}

Until April 5, 2020 in Italy, 10\% of the infected individuals were healthcare workers, and a total of 105 healthcare workers died due to COVID-19 (2). In a community that directly encounters 
patients infected with COVID-19, it is quite challenging to prevent this spread, and the only effort that can be taken is strict measures. In the United States, at the beginning of the pandemic (February-2020), 43 of 121 healthcare professionals who had contact with only one infected patient developed symptoms within 14 days, and three showed PCR positivity (3). Until April 9, 2020, COVID-19 positivity was reported in 9282 healthcare professionals in the United States (4). This situation shows that health professionals must protect themselves first, in order to achieve victory in the fight against the pandemic. There are precautions to be taken regarding health professionals (5). The Turkish Surgical Society has also conducted a study on the precautions surgeons should take during this process (6).

This survey was conducted to assess the attitudes of surgeons in Turkey during the early period of COVID-19 pandemic. The aim of this study was to determine the current situation and to shed light on the future measures. Survey questions were also prepared for this purpose by the researchers who followed the relevant guidelines.

Vast majority of the survey participants are from the metropolitan areas, however, there are participants from all regions of the country and it is seen that this diversity is also provided in hospital types that were responded. $91.8 \%$ of these hospitals were affected at different levels from COVID-19. It is seen that surgeons have changed their daily surgical practices and postpone elective cases. Most of the Turkish surgeons have arranged their working routines only to operate emergency and cancer cases and suspended training or meeting activities during the pandemic process. It is also seen that most surgeons work in other places of concern for the treatment of COVID-19 patients. We think that this is a successful early reflex across the country.

In the preoperative period, it is seen that Turkish surgeons evaluate their patient in terms of COVID-19 either with symptomatic evaluation, thorax imaging or a PCR test. We think that symptomatic evaluation should be done to all patients, and all emergency cases should be treated as a positive case, and in elective cancer cases, thorax tomography, which is already part of metastase screening, should be evaluated (7). In non-urgent suspected patients, PCR testing may be required before surgery. The proportion of surgeons who did not make any evaluation (6.8\%) likely belongs to surgeons working in unaffected hospitals. However, considering the spread of the disease, we think that these surgeons also should take precautions. Our survey showed that the number of surgeons with a suspicious or positive patient contact is not low at all. However, almost half of the participants do not receive informed consent from patients regarding COVID-19. Patients can become infected with COVID-19 during their hospital stay for the operation. Surgery, especially in cancer patients, increases the mortality rate due to COVID-19 (8). There is legal uncertainty about these issues, and it is essential to obtain a consent form from patients for this information. Our survey study shows that surgeons should be informed about this issue.

Vast majority of Turkish surgeons has postponed benign elective cases but there is difference in approach to malignant elective cases. There are many guidelines on this subject (9-14). Currently, it is observed that one third of Turkish surgeons perform malignant patient management as before the pandemic. This may cause problems in hospital resource management or increase the risk of patients during the pandemic. The management of these patients should be done in accordance with the guidelines and therefore, surgeons should be informed. We are in preparation of a review on this topic.

It is seen that Turkish surgeons use the necessary personal protection equipment in their internal and external OR routines. It is also seen that the use of boots is very low in the operating room. Surgeons must be informed about this. Almost half of the participants stated that they did not have a separate operating theatre for COVID-19 patients. The possibilities of each hospital are different, but we think that a regulation should be made for the creation of these operating theaters in the cities.

There are very few studies on viral transmission in open or minimally invasive surgery, and the evidence levels of these studies are low. Our review mentioned above showed that laparoscopic surgery seems to be advantageous both in terms of low risk to the patient and early postoperative discharge time. However, the risk of transmission by gases that spread from the abdomen to the operating room environment and the risk of putting the instruments and items in the operating room and other personnel at risk are not clear yet. Open surgery is advantageous because it reduces the duration of surgery and minimizes the risk of transmission to non-operating personnel. However, the risk of direct contact with body fluids and the transmission of fume from the energy devices used is not yet clear. Turkish surgeons think open surgery is safe and upper endoscopic and laparoscopic surgery is risky in the pandemic process. The surgeons' attitudes towards robotic surgery are interesting. Although it is not very different with laparoscopic surgery, robotic surgery is considered to be safe. The perception on this issue is unknown. Whether the operation is minimally invasive or not, all surgeons must take risk-reducing measures. It is seen that the rate of taking these measures in Turkish surgeons is low. Surgeons should be informed in terms of these measures to protect themselves and their team.

Like every human being in the world, Turkish surgeons are concerned about getting ill or infecting their relatives. For this reason, it was observed that approximately $24 \%$ of the participants changed their social life conditions. This is a relatively high rate and the need for psychological support of physicians should be considered in this process and at the end of the process. It 
is promising that the number of infected workers is quite low among our colleagues. However, this should not cause us to relax. Pandemic is an ongoing process, and it should be kept in mind that strict rules are still valid.

\section{CONCLUSION}

Turkish surgeons have managed to get a quick reaction from the start of the pandemic. However, there are still differences in preoperative patient evaluation and operation selection and precautions during the operation. Surgeons should also be informed about the management of malignant patients.

\section{ACKNOWLEDGEMENTS}

The authors would like to thank all Turkish surgeons who participated and supported the survey and worked devotedly during the time of the pandemic.

Ethics Committee Approval: This study was approved by the Ministry of Health, General Directorate of Health Services.

Peer-review: Externally peer-reviewed.

Author Contributions: Concept - M.K.Ç., E.B.B.; Design - M.K.Ç., E.B.B.; Supervision - E.B.B., M.M.Ö.; Resource - M.K.Ç., M.Y.Ö., E.P.; Materials - M.K.Ç., M.Y.Ö., E.P.; Data Collection and/or Processing - M.K.C.., M.Y.Ö., M.M.Ö.; Analysis and Interpretation - M.K.Ç., E.B.B., M.M.Ö.; Literature Review - M.K.Ç., M.Y.Ö., M.M.Ö.; Writing Manuscript - M.K.Ç.; Critical Reviews - E.B.B., M.M.Ö.

Conflict of Interest: No conflict of interest was declared by the authors.

Financial Disclosure: The authors declared that this review has received no financial support.

\section{REFERENCES}

1. Li S, Li XD, Wang GP, Liang C, Jing JP, Liu MM, et al. Consideration of surgeons participating in COVID-19 emergency medical rescue. Zhonghua Wai Ke Za Zhi 2020 Apr 7; 58(0): E025. doi: 10.3760/ cma.j.cn112139-20200317-00226. [CrossRef]

2. Chirico F, Nucera G, Magnavita N. COVID-19: protecting healthcare workers is a priority. Infect Control Hosp Epidemiol. 2020 Apr 17: 1-4. doi: 10.1017/ice.2020.148. [CrossRef]

3. Heinzerling A, Stuckey MJ, Scheuer T, Xu K, Perkins KM, Resseger H, et al. Transmission of COVID-19 health care personnel during exposures to a hospitalized patient - Solano County, California, February 2020 MMWR Morb Mortal Wkly Rep 2020; 69(15):472-6. [CrossRef]
4. CDC COVID-19 Response Team. Characteristics of health care personnel with COVID-19- United States, February 12-April 9, 2020. MMWR Morb Mortal Wkly Rep 2020; 69(15): 477-81. [CrossRef]

5. Agalar C, Öztürk Engin D. Protective measures for COVID-19 healthcare providers and laboratory personnel. Turk J Med Sci 2020 Apr 17. doi: 10.3906/sag-2004-132. [CrossRef]

6. Karaca AS, Ozmen MM, Uçar AD, Yastı AÇ, Demirer S. General surgery operating room practice in patients with COVID-19. Turk J Surg 2020; 36(1). doi: 10.5578/turkjsurg.202001. [CrossRef]

7. GokAFK, Eryılmaz M, Ozmen MM, Alimoglu O, Ertekin C, Kurtoglu MH. Recommendations for trauma and emergency general surgery practice during COVID-19 pandemic. Ulus Travma Acil Cerrahi Derg 2020; 26(3): 335-42. [CrossRef]

8. Liang W, Guan W, Chen R, Wang W, Li J, Xu K, et al. Cancer patients in SARS-CoV-2 infection: a nationwide analysis in China. Lancet Oncol 2020; 21(3): 335-7. [CrossRef]

9. American College of Surgeons COVID-19 Guidelines for Triage of Colorectal Cancer Patients (https://www.facs.org/covid-19/clinical-guidance/elective-case/colorectal-cancer) [CrossRef]

10. Society for Surgical Oncology Resource for Management Options of Colorectal Cancer During COVID-19 (https://www.surgonc.org/ wp-content/uploads/2020/04/Colorectal-Resource-during-COVID-19-4.6.20.pdf) [CrossRef]

11. Society for Surgical Oncology Resource for Management Options of GI and HPB Cancers During COVID-19 (https://www.surgonc. org/wp-content/uploads/2020/04/Gl-and-HPB-Resource-duringCOVID-19-4.6.20.pdf) [CrossRef]

12. Society of American Gastrointestinal and Endoscopic Surgeons Recommendations Regarding Surgical Management of Gastric Cancer Patients During the Response to the COVID-19 Crisis (https://www. sages.org/sages-recommendations-surgical-management-gastriccancer-covid-19-crisis/) [CrossRef]

13. Society of American Gastrointestinal and Endoscopic Surgeons - AHPBA Recommendations Regarding Surgical Management of HPB Cancer Patients During the Response to the COVID-19 Crisis (https://www. sages.org/sages-ahpba-recommendations-surgical-managementof-hpb-cancer-covid-19/) [CrossRef]

14. Society of American Gastrointestinal and Endoscopic Surgeons Recommendations Regarding Surgical Management of Colorectal Cancer Patients During the Response to the COVID-19 Crisis (https:// www.sages.org/recommendations-surgical-management-colorectal-cancer-covid-19/) [CrossRef] 
SURVEY. General Surgery COVID-19 Pandemic Attitude Survey

1- Name of the city you work in

Write the name of the city you are currently working in

2-Type of the institution you work in?

Mark only one item.

-University Hospital

-Affiliated Hospital

-Training and Research Hospital

-State Hospital

-City Hospital

-Private Hospital

3- Which of the following definitions does the hospital you work in comply with during the current pandemic process?

Mark only one item.

-Unaffected: No COVID-19 patient

-Semi-Urgent: Few COVID-19 patients, hospital resources not exhausted, institution still has ICU ventilator capacity and COVID-19 trajectory not in rapid escalation phase.

-Urgent: Many COVID-19 patients, ICU and ventilator capacity limited, OR supplies limited

- Emergent: Crisis situation in which all resources and intensive care beds are directed to COVID-19 patients

4- How did you arrange your daily training / council and meetings during the pandemic?

Mark only one item.

-As usual

-We reduced the number of participants

-We continued as video conference

-We canceled them

5- What is the change in your daily surgical practice during the pandemic process?

Mark only one item.

- I continue my daily practice as before the pandemic (ignoring the number of cases)

- I canceled benign cases. I only operate cancer and emergency cases

-I canceled benign and cancer cases. I only operate emergency cases

-I completely canceled my daily practice

6- If you canceled your daily practice completely, what is the main reason?

Mark only one item.

-I am on administrative leave due to age or comorbidity

- I am on administrative leave due to the flexible work program

-I do not perform operations due to the lack of personal protective equipment.

- I do not perform operations due to the lack of intensive care.

-I do not perform operations due to my concerns about COVID-19

-I do not perform operations because I am currently working in other services where patients with COVID-19 are treated.

-Other:

7- If you continue to perform operations during the pandemic, how do you evaluate the patients in terms of COVID-19 in the preoperative period? (Except for emergency cases)

Mark only one item.

-Routine test for everyone (PCR / antibody test) and wait for the result

-Routine thorax CT for everyone and wait for the result

-I just evaluate the symptoms (fever, cough, dyspnea)

-I do not perform additional evaluation but intervene if it is symptomatic in the process

- I accept everyone as positive and take precautions accordingly.

8- Do you get a separate consent form related to COVID-19 from the patient you will operate?

Mark only one item.

-Yes

-No 
SURVEY. General Surgery COVID-19 Pandemic Attitude Survey (continue)

9- Have you operated COVID-19 suspected or positive patients?

Mark only one item.

-I have not

-Operate suspected patient

-Operate positive patient

-I do not know

10- Have you ever got in contact with COVID-19 suspect or positive patient?

Mark only one item.

-I have not

-Contact with suspected patient

-Contact with positive patient

-l do not know

11- What is your operation management to malignant patients during the pandemic process?

Mark only one item.

-I perform the same management as before the pandemic process

-I delay all patients, if possible

-I postpone patients at risk of age and comorbidity

- I refer to secondary treatment (RT / CT / interventional / endoscopic) options and postpone surgery

- I refer patients at risk of age and comorbidity to secondary treatment (RT / CT / interventional / endoscopic) options and postpone surgery

-I redirect patients to a different center

12- What is your operation management to benign patients during the pandemic process?

Mark only one item.

-I perform the same management as before the pandemic process

-I delay all patients if possible

- l postpone patients at risk of age and comorbidity

-I refer to secondary treatment interventional / endoscopic) options and postpone surgery

- I refer patients at risk of age and comorbidity to secondary treatment (interventional / endoscopic) options and postpone surgery

-I redirect patients to a different center

13-Personal protective equipments you use out of the operating room

More than one box can be checked.

-I use N95 or similar masks

-I use surgical mask.

- I use protective glasses or barrier.

-I use protective gowns or overalls.

-I use protective boots

-I don't use any protective equipment.

-Other:

14- Do you have a separate operating room for COVID-19 suspected or positive patients?

Mark only one item.

-Yes

-No

15-Personal protective equipments you use inside the operating room

More than one box can be checked.

-I use N95 or similar masks

-I use surgical mask.

-I use protective glasses or barrier.

-I use protective gowns or overalls.

-I use protective boots

-I don't use any protective equipment.

-Other: 


\section{SURVEY. General Surgery COVID-19 Pandemic Attitude Survey (continue)}

16- Which of the following operation methods do you think has the highest risk for the surgeon in terms of COVID-19 infection transmission?

Mark only one item.

-Open Surgery

-Laparoscopic Surgery

-Upper Endoscopic Surgery

-Robotic Surgery

17- Which of the following operation methods do you think has the least risk for the surgeon in terms of COVID-19 infection transmission? Mark only one item.

-Open Surgery

-Laparoskopic surgery

-Upper Endoscopic Surgery

-Robotic Surgery

18-Do you take additional measures (low pressure / filter) for risk reduction of COVID-19 transmission while performing minimally invasive surgery (Laparoscopic / Robotic) during the pandemic?

Mark only one item.

-Yes

$-\mathrm{No}$

19- Do you take additional measures for risk reduction of COVID-19 transmission while performing open surgery during the pandemic? Mark only one item.

-Yes

-No

20- Have you had COVID-19 test or imaging?

Mark only one item.

-Yes

-No

21- Have you received COVID-19 treatment?

Mark only one item.

-Yes

$-\mathrm{No}$

22-Where do you live during the pandemic?

Mark only one item.

-With my family at home

-Alone at home

-Hotel / Guesthouse

-Other

23- Which of the following emotions do you experience during the pandemic?

Multiple boxes can be checked

-I am concerned about getting infected with COVID-19

-I am concerned to carry COVID-19 infection to my relatives.

-I am not concerned about getting COVID-19 infection or carrying it to someone else with the precautions I have taken. 


\section{ORIJINAL ÇALIŞMA-ÖZET}

Turk J Surg 2020; 36 (2): 137-146

\section{COVID-19 salgını sırasında Türk genel cerrahlarının tutumu: "Genel cerrahi COVID-19 pandemi tutum araştırması" sonuçları}

Muhammet Kadri Çolakoğlu ${ }^{1}$, Yiğit Mehmet Özgün ${ }^{1}$, Erol Pişkin ${ }^{1}$, Erdal Birol Bostancı ${ }^{1}$, Mehmet Mahir Özmen ${ }^{2}$

1 Sağlık Bilimleri Üniversitesi, Ankara Şehir Hastanesi, Genel Cerrahi Bölümü, Ankara, Türkiye

${ }^{2}$ Istinye Üniversitesi Tıp Fakültesi, Genel Cerrahi Anabilim Dalı, İstanbul/Liv Hospital Ankara, Genel Cerrahi Bölümü, Ankara, Türkiye

\section{ÖZET}

Giriş ve Amaç: Tüm dünya COVID-19 salgını ile mücadele etmektedir ve sağlık profesyonelleri bu mücadeleden en çok etkilenen gruptur. Bu çalışmanın amacı, genel cerrahların COVID-19 hakkındaki bilgilerini değerlendirmek ve çalışma arkadaşlarımızın tutumunu ve mevcut durumunu anlamaktır.

Gereç ve Yöntem: Tanımlayıcı tipteki bu çalışma, Türkiye'nin farklı bölgelerinde çalışan genel cerrahlardan oluşmaktadır. Katılımcıların demografik özelliklerini, iş yeri özelliklerini, günlük çalışma uygulamalarındaki değişimi ve pandemik süreçteki tutumlarını belirlemek için 23 sorudan oluşan bir anket hazırlanmıştır.

Bulgular: Toplam 332 form değerlendirildi. Anket sonuçları cerrahların çoğunun günlük cerrahi uygulamalarını değiştirdiğini göstermektedir. Birçok cerrah COVID-19'un tedavisine aktif katılmaktadır. Çoğu benign olgu ertelenirken, malign olguların yönetimi ise farklılık göstermektedir. Ameliyat öncesi hastaların ve ameliyat tipinin değerlendirilmesinde de farklılıklar vardır. Kişisel koruyucu önlemlere uyulduğu görülmektedir. Enfekte cerrahların oranı düşük olmakla birlikte, cerrahların çoğunun enfeksiyona yakalanma konusunda endişeleri mevcuttur.

Sonuç: Türk cerrahlar pandeminin başlangııından itibaren hızlı bir tepki almayı başardılar. Bununla birlikte, ameliyat öncesi hasta değerlendirmesi ve operasyon seçimi ile operasyon sırasında alınacak önlemler arasında hala farklılıklar bulunmaktadır. Cerrahlar malign hastaların yönetimi hakkında da bilgilendirilmelidir.

Anahtar Kelimeler: COVID-19, koronavirüs, pandemi, cerrahi, anket

Doi: $10.5578 /$ turkjsurg.4809 